\title{
KEBERADAAN ETNIS CINA DAN PENGARUHNYA DALAM PEREKONOMIAN DI ASIA TENGGARA
}

\author{
Oleh : Danar Widiyanta*
}

\begin{abstract}
Abstrak :
Keberadaan Etnis Cina dalam melakukan aktivitas perdagangan di Asia Tenggara sudah terjadi jauh sebelum kedatangan bangsa Barat. Ketika orang Eropa datang di kawasan Asia Tenggara pada abad ke-16 dan awal abad ke-17, orang Cina sudah bermukim di kota-kota pelabuhan utama. Saudagar-saudagar Cina meskipun belum begitu banyak namun tersebar luas di seluruh kawasan ini. Dalam beberapa abad kemudian, orang Cina bertindak sebagai pedagang perantara atau bekerja sebagai buruh serta produsen berskala kecil. Ketika jumlah mereka semakin banyak, mereka kemudian mendominasi perekonomian pasar di kawasan Asia Tenggara.
\end{abstract}

Kata Kunci : Etnis Cina, Perekonomian, Asia Tenggara.

\section{A. Pendahuluan.}

Orang Cina datang ke kawasan Asia Tenggara sudah sejak awal sejarah untuk menukarkan barang-barang Cina seperti sutra dan porselin dengan rempah-rempah, obat-obatan dan barang-barang yang aneh dan langka dari kawasan Asia Tenggara ini. Pada abad ke- 16 dan awal abad ke 17, ketika orang Barat datang ke kawasan Asia Tenggara, mereka mendapatkan saudagarsaudagar Cina berjumlah sedikit tetapi tersebar luas di kawasan ini. Dalam beberapa abad kemudian, mereka bertindak sebagai pedagang perantara atau bekerja sebagai buruh serta produsen berskala kecil. Ketika jumlah mereka semakin membesar, mereka lalu mendominasi perekonomian pasar di kawasan ini.

\section{B. Identitas Orang Cina Asia Tenggara.}

Orang Cina tidak pernah memiliki konsep identitas, kecuali konsep tentang kecinaan, yaitu Cina dan bukan Cina. Kajian mengenai identitas orang Cina sebagian besar dilakukan oleh ilmuan sosial sepanjang beberapa

\footnotetext{
* Dosen Prodi Ilmu Sejarah Jurusan Pendidikan Sejarah FISE UNY
} 
dasawarsa terakhir tidak mengarah kepada suatu konsep identitas ${ }^{1}$. Pada periode sebelum 1950, konsep identitas belum banyak digunakan. Ada dua cara orang Cina memandang kecinaan mereka, yang pertama dapat disebut sebagai identitas nasional Cina, sedangkan yang lainnya lebih tradisional dan berkiblat pada masa silam yaitu dikenal dengan identitas historis. Identitas historis lebih menekankan pada nilai-nilai dan simbol-simbol budaya masa lampau. Sebelum Perang Dunia II, masalah kecinaan dianggap sebagai hal yang sederhana saja. Semua orang yang menganggap dirinya Cina adalah orang Cina. Mereka sadar akan sistem keluarga mereka, tempat asal mereka di Cina dan pertalian mereka dengan orang-orang Cina yang lain, baik Cina daratan maupun di beberapa bagian lain di kawasan Asia Tenggara.

Faktor-faktor tempat asal dan pertalian budaya menciptakan sentimen yang dapat diperkuat dan diperluas melalui kisah-kisah mengenai orang Cina pada masa lampau dan alasan-alasan bagi kebangaan terhadap tradisi agung peradaban Cina.Hal ini menghasilkan identitas historis karena menekankan bagaimana kesemuanya nilai-nilai keluarga, asal-usul merka dan loyalitas subetnis tradisional maupun simbol-simbol dari masa lampau Cina yang agung menopang kecinaan mereka. Karena sebagian besar identitas historis melihat ke masa lampau dan jarang menyusahkan sehingga para pejabat kolonial serta elit pribumi Asia Tenggara mengizinkan orang Cina melestarikan kecinaannya agar berhasil memainkan pera ekonomi mereka.

Sepanjang 1920-an dan 1930-an, identitas historis diserang oleh suatu nasionalisme yang baru dan agresif dari Cina, yang didasarkan pada konsep ras dan bangsa dari Sun Yat Sen. Identitas nasional Cina menjadi riil bagi orang Cina lokal berkat keberhasilan usaha banyak guru dan wartawan yang direkrut dari Cina dalam rangka menyebarluaskan gagasan identitas nasional tersebut. Kegiatan ekspansionis Jepang di Cina yang memicu perang Cina-Jepang dan akhirnya mengarah pada penyerbuan terhadap Asia Tenggara menjadikan identitas ini lebih kuat dan lebih emosional ${ }^{2}$.

${ }^{1}$ Wang Gungwu, "Kajian tentang Identitas Orang Cina Asia Tenggara”, dalam bukunya Jeniffer Cushman dan Wang Gungwu, Perubahan Identitas Orang Cina di Asia Tenggara, Jakarta : Pustaka Utama Grafiti, 1991, hlm. 1-3.

${ }^{2}$ Victor Purcell, The Chinese in Southeast Asia, London : Oxford University Press, 1968, hlm 586-610. 
Sesudah berakhirnya Perang Dunia II, di kalangan orang Cina Asia Tenggara muncul suatu identitas nasional Cina. Kebanyakan pemimpin politik pribumi yang baru muncul, merasakannya sebagai suatu bahaya. Di negara seperti Filipina, Indonesia, Myanmar dan Vietnam, di mana jumlah orang Cina relatif kecil, identitas nasional Cina dianggap dapat dirangkul dan dapat digantikan dengan identitas nasional lokal baru yang ditawarkan kepada orang Cina. Namun di Malaya yang memiliki populasi orang Cina yang besar, identitas nasional Cina merupakan ancaman yang sulit diatasi dan membutuhkan penanganan yang seksama. Hal ini bertambah rumit karena sebagian besar nasionalis muda Cina telah terpengaruh komunisme sehingga memihak pada perjuangan kemerdekaan antikolonial di seluruh dunia, bukan memihak Cina sebagai satu bangsa.

Selama beberapa dasawarsa hingga 1950, sebagian identitas historis Cina tampaknya digantikan oleh identitas nasional Cina. Namun tidak semua orang Cina mendukung nasionalisme Cina, sebagian seperti di Birma, Vietnam dan Filipina mencoba memihak pada gerakan nasionalisme setempat dan bersedia menerima identitas baru yang secara teoritis melintasi batas-batas rasial dan bahkan nasional menuju kelas ekonomi ${ }^{3}$.

Pada tahun1950-an dan 1960-an, jalinan identitas orang Cina terutama jalinan politik sudah mulai dipelajari. Di Malaya, orang Cina mencapai hampir separuh populasinya. Secara keseluruhan komunitas Cina lokal yang kuat bersedia meninggalkan identitas nasional Cina dan menggantikannya dengan identitas nasional Malaya yang baru, namun tanpa meninggalkan identitas historis sebagai pembentuk identitas nasional Malaya. Identitas komunal terbatas terjadi di Malaysia , namun peluang untuk memperoleh pengaruh politik boleh jadi semakin berkurang. Di bawah tekanan yang keras, identitas komunal bisa diganti dengan konsep identitas etnis yang lebih netral dan tidak agresif. Sementara di wilayah lain di Asia Tenggara aspirasi politik meraka terintegrasi namun tetap diizinkan melestarikan sebagian identitasbudaya Cinanya. Dengan terbentuknya negara kebangsaan modern, orang Cina mendapatkan pilihan untuk asimilasi atau integrasi. Hal ini menuntut sikap yang lebih luwes dan lebih berpandangan ke depan terhadap kebudayaan dan pengertian budaya Cina yang baru.

\footnotetext{
${ }^{3}$ Yoshihara Kunio, Kapitalisme Semu Asia Tenggara, Jakarta : LP3ES , 1990,
} hlm 4. 
Dalam kontek perdebatan mengenai asimilasi dan integrasi, kelebihan gagasan identitas budaya terletak pada dihindarinya retorika emosional di balik identitas rasial. Identitas budaya sebagai sebuah konsep secara tidak langsung menyatakan bahwa negara kebangsaan dapat hidup dengan banyak kebudayaan dan bahkan kebudayaan nasional yang baru dapat diperkaya dengan kebudayaan daerah/lokal tertentu. Untuk kajian mengenai orang Cina Asia tenggara, konsep identitas budaya membuka kemungkinan untuk mengkaji tidak hanya bagaimana orang menopang identitas Cina mereka, namunjuga bagaimana sebagian mereka dapat melakukan asimlasi total dan menerima suatu identitas bukan Cina yang sepenuhnya baru.

Menjelang tahun 1970-an, kebanyakan di antara etnis Cina sudah menjadi warga negara sepanjang dua dasawarsa dan tidak pernah menimbulkan kesulitan politik. Proses domestikasi warga negara peranakan Cina mengakibatkan pemerintah setempat di Asia Tenggara memandang mereka dengan tekanan perhatian yang berbeda. Kecuali di Malaysia, kelompok minoritas Cina tidak dianggap sebagai suatu jenis ancaman eksternal, melainkan diakui tidak begitu mengganggu dibandingkan dengan sebagian minoritas pribumi, seperti Karen di Myanmar, Melayu di Thailand ataupun Moro di Filipina.

Identitas orang Cina di Asia Tenggara pada dekade 1970-an tidak dapat dipisahkan dengan aktivitas ekonomi orang Cina di kawasan Asia Tenggara ini. Peranan usaha orang Cina yang pesat di Asia Tenggara secara khusus bisa mempengaruhi identitas orang Cina. Kita dapat memperkirakan bahwa semakin kuat tingkat integrasi atau asimilasi, semakin penting pula sumbangannya pada identitas kelas di dalam negeri. Kalau integrasi lemah atau bila pemerintah nasional dianggap mendiskriminasikan warga negara peranakan Cina, suatu jenis kepentingan kelas yang lain akan muncul dan para elite ekonomi peranakan Cina akan tergoda untuk melakukan bisnis menurut garis etnis dengan sesama Cina di negara lain. Ini akan cenderung memperkuat identitas etnis orang Cina di seluruh kawasan Asia Tenggara, dan bahkan di beberapa bagian dunia yang lain dengan mengorbankan identitas lokal elite ekonomi pribumi ${ }^{4}$.

\footnotetext{
${ }^{4}$ Wang Gungwu, Ibid., hlm. 11-13.
} 


\section{Awal Masuknya Modal Cina di Asia Tenggara}

Dihampir semua negara di Asia Tenggara, peran ekonomi kaum minoritas Cina perantauan telah berubah mengikuti garis yang nyaris sama sejak bagian terakhir abad ke-19. Pada masa ini saudagar Cina mulai mengungguli yang lain, orang Cina ini mengerti bahasa Inggris dan berkembang melalui hubungan bisnis dengan para saudagar atau pejabat Eropa. Kebangkitan lembaga kapitalis Cina sebagai suatu akibat lain dari perubahan ekonomi yang sangat penting yang dimulai sekitar $1870^{5}$. Paling tepat adalah menganggap Di Indonesia misalnya, kemajuan mereka dari pekerjaan yang umumnya berstatus rendah sebagai buruh imigran atau pedagang kecil pada awal abad ke-20 menuju posisi idaman yang lebih tinggi di tangga ekonomi pada tahun 1970-an. Hal serupa terjadi juga dengan kemajuan kelompok atau individu Cina lain di Muangthai, Malaysia, Singapura dan Filipina. Di semua negara di atas, etnis Cina kini merupakan bagian penting dari kelas menengah perkotaan. Mereka menggenggam kekuasaan ekonomi yang sangat besar di negara-negara Asia tenggara, meskipun belum banyak memiliki kekuasaan dan pengaruh politik, kecuali di Singapura ${ }^{6}$.

Lembaga-lembaga kapitalis Cina yang pertama muncul di Malaya terjun dalam penambangan timah dan di Indonesia dalam produksi gula. Produk-produk ini banyak diminta di barat pada akhir abad ke-19, sehingga keuntungan besar menunggu mereka yang dapat memasoknya. Produksinya dalam skala besar dimungkinkan bagi orang-orang Cina dengan tata hukum kelembagaan yang baru yang diciptakan oleh pemerintah kolonial model Barat. Dalam periode ini ada dua tipe lembga kapitalis Cina, yang pertama tercipta melalui hubungan bisnis dengan lembaga lembaga Barat. Sebagian menjadi kaya dan membangun organisasi yang besar melalui hubungan dagang dengan para saudagar dan prodisen Barat. Yang kedua lembaga kapitalis Cina yang beroperasi terutama di lingkungan Cina. Mereka memberi bahan baku pada para petani pribumi kemudian mengolahnya untuk konsumsi orang Cina, seperti beras dan bahan makanan lainnya. Terdapat juga tipe campuran, di

\footnotetext{
${ }^{5}$ Yoshihara Kunio, Ibid., hlm 57.
}

${ }^{6}$ J.A.C. Mackie, "Peran Ekonomi dan Identitas Etnis Cina Idonesia dan Muangthai" dalam bukunya Jeniffer Cushman dan Wang Gungwu, Perubahan Identitas Orang Cina di Asia Tenggara, Jakarta : Pustaka Utama Grafiti, 1991, hlm. 291. 
mana perusahaan dagang Cina harus berurusan dengan para pedagang kecil Cina yang mengumpulkan barang-barang yang akan mereka impor ke Barat.

Kebangkitan lembaga kapitalis Cina terjadi terutama kerena akspansi ekonomi yang tercipta oleh masuknya modal Barat secara besar-besaran menyusul Ravolusi Transportasi dan perubahan pada tatanan hukumkelembagaan. Orang Cina yang mendominasi perekonomian pasar, kini terpecah dalam supperklas dan massa. Mereka yang sukses mempunyai kelihaian bisnis, kemampuan berorganisasi dan karekteristik pribadi yang berhasil mebuat mereka memperoleh kepercayaan di kalangan kounitas Cina. Tetapi dalam kebangkitan mereka, banyak yang mendapat bantuan perlindungan politik dan konsesi monopoli dari pemerintah. Terutama di Indonesia dan Thailand, koneksi pemerintah ini penting pada fase awal akumulasi modal dengan mendapat hak menarik pajak yang menguntungkan.

Orang Cina juga mendirikan lembaga perbangkan, bersaing dengan bank Barat, untuk memenuhi kebutuhan keuangan dengan kemunitas mereka. Pada mulanya orang Cina hanya punya sedikit ketrampilan dalam perbangkan. Untuk mengatasinya mereka merekrut orang Cina sendiri yang bekerja di bankbank Barat atau menyewa orang Barat untuk jabatan managerial.

Kekurangan modal dan teknologi untuk orang cina, nampak pada peleburan timah. Peleburan timah lebih efisien dengan metode padat modal dibandingkan dengan metode tradisional. Juga pada produksi gula memerlukan modal yang besar, sehingga hanya sedikit orang Cina yang mampu menerobosnya. Masalah-masalah yang dihadapi modal Cina dalam persaingan dengan modal Barata sebagian besar karena kebijaksanaan pemerintah kolonial yang deskriminatif. Misalnya di Malaya, pemerintah kolonial memberi hak monopoli atas ekspor biji timah dari Selangor dan Sungei Ujong.

Depresi besar tahun 1929, telah menyebabkan sejumlah bisnis orang Cina gulung tikar. Di Singapura misalnya, beberapa bank harus bubar akibat depresi ini. Sebagian perusahaan Cina rupanya telah menyesuaikan diri dengan depresi secara lebih baik dengan melakukan inovasi-inovasi dan memadukannya dengan pemilikan dan praktek managemen Cina Tradisional. Bidang bidang yang tidak langsung dipengaruhi oleh depresi, telah melahirkan lembaga kapitalis baru. Di Muangthai, keluarga Wanglee yang berkembang 
karena perniagaan beras, kemudian berekspansi dalam bidang perbangkan, pelayaran serta asuransi ${ }^{7}$.

Depresi ekonomi telah menghentikan ekspansi modal Barat di Asia Tenggara, dan perang Pasifik merupakan pukulan yang menghancurkannya. Namun masa sesudah perang justru merupakan masa ekspansi bagi modal Cina. Sebagai satu unsur dalam negeri, Cina memperoleh keuntungan dari nasionalisme modal asing, dan proteksi serta promosi modal dalam negeri. Di Indonesia misalnya bagaimana Liem Sioe Liong dipercaya membangun pabrik semennya yang pertama tahun 1975 dan 7 buah lagi pada dasawarsa berikutnya. Di bidang perbangkan, Muangthai menyediakan lingkungan yang menguntungkan bagi modal Cina. Tahun 1938 bang asing lebih banyak dibanding bang Muangthai, namun sepuluh tahun berikutnya keadaan berbalik ada 13 bank Muangthai dan 10 bank asing.

Kombinasi kelihaian bisnis orang Cina dengan kebijaksanaan nasionalistis dari pemerintah tampaknya telah membuat modal Cina unsur modal terpenting di Asia Tenggara. Di bidang-bidang yang utama, tidak ada modal swasta pribumi yang lebih penting daripada modal Cina. Di Singapura, tidaklah mengherankan bila modal Cina mendominasi sepenuhnya modal pribumi, karena orang Cina merupkan tiga perempat penduduk. Di Mungthai, orang Cina, meskipun kelompok minoritas, mendominasi kapitalismenya. Di Indonesia, posisi para kapitalis pribumi lebih penting tetapi mereka jauh kurang berarti dibandingkan dengan kapitalis Cina, contohnya, dari 10 bank swasta terbesar hanya satu bank yang dikendalikan pribumi. Hanya dalam kapitalisme Filipina, pribumi lebih baik dibanding orang Cina.

Sementara dominasi orang Cina dalam kapitalisme dan perekonomian pasar tidak membawa masalah bagi pemerintah di Singapura, di mana orang Cina merupakan mayoritas besar, tetapi tidak untuk negara-negara Asia Tenggara lainnya tidak selalu senang dengan keadaan ini dan telah melakukan langkah-langkah diskriminasi ${ }^{8}$. Di Muangthai, pemerintah telah mengintervensi perekonomian guna mengurangi ketergantungan kapitalisme asing termasuk Cina. Tahun 1950-an di Muangthai terdapat banyak perusahaan milik negara dalam manufaktur, keperluan umum, perdagangan dan jasa. Di Filipina, sektor

\footnotetext{
${ }^{7}$ Yoshihara Kunio, op. cit., hlm 67.

${ }^{8}$ Ibid., hlm. 86.
} 
swasta pribumi lebih digalakkan oleh pemerintah Tahun 1950-an Filipina membatasi alokasi devisa bagi orang Cina dan menghalangi sektor tertentu dalam perdagangan. Indonesia juga pernah mencoba mengurangi ketergantungan pada orang Cina dengan meningkatkan kewirausahaan pribumi.Sementara di Malaysia pemerintah mengambil langkah-langkah pertama untuk mempromosikan kewirausahaan pribumi di tahun 1960-an.

Kebencian umum terhadap orang Cina di berbagai bagian masyarakat di hampir semua negara Asia tenggara sering ditimbulkan oleh fakta bahwa mereka mendominasi peran ekonomi. Kompeteisi antara usahawan Cina dan pribumi kerap kali menjadi pemicu permusuhan terhadap orang Cina. Ketika orang dikesampingkan dari peran ekonomi yang sangat mereka inginkan, mereka cenderung memanipulasi kebencian umum terhadap orang Cina dalam bentuk tekanan politik atau diskriminasi atau tindak kekerasan massal. Persaingan ekonomi menjadi dasar ketidaksenangan yang berpengaruh pada meletusnya berbagai kerusuhan anti Cina di semua negara Asia tenggara. Namun rasionalitas ekonomi yang ada telah menghalangi pemerintahpemerintah Asia Tenggara mengubah struktur kepemilikan secara radikal dan kendala ini telah memungkinkan orang Cina mendominasi kapitalisme di Asia Tenggara sampai sekarang.

\section{Pengaruh Etnis Cina dalam Perekonomian Asia Tenggara}

Etnis Cina mendominasi perekonomian di Asia Tenggara sudah sejak permulaan abad ke-20, seperti terjadi di Thailand, Philipina, Vietnam, dan Indonesia, sedangkan di Birma dikuasai oleh orang India (chettiar). ${ }^{9}$ Selanjutnya, pada tahun 1970-an pertumbuhan ekonomi Asia Tenggara tidak dapat dilepaskan dari politik ekonomi Asia Timur. Apakah negara-negara neoconfusianisme bersedia membantu negara-negara Asia Tenggara yang masih tertinggal ? Tidak diragukan lagi bahwa ada hubungan dagang antaretnis Cina, ${ }^{10}$ jaringan bisnis etnis Cina sudah terwujud dan memiliki peran dalam ekonomi regional Asia Tenggara. Sesuai dengan teori “angsa terbang” Jepang, negara maju memberikan bantuan dan bimbingan kepada negara-negara

\footnotetext{
${ }^{9}$ Abdullah Zakaria Ghazali (ed.al.). Sejarah Asia Tenggara, Asia Selatan dan
} Asia Timur 1800-1963. Selangor: Fajar Bhakti, 2000,hlm.320).

${ }^{10}$ Jurnal Studi Jepang (1992). Vol 1 N0. 2, hlm. 47. 
tertinggal di Asia Tenggara, yang pada akhirnya negara-negara tertinggal akan menyamai negara maju.

Realisasi teori itu diperlihatkan dengan mengalirnya investasi langsung dari Jepang dan Taiwan terhadap negara-negara Asia Tenggara. Investasi Jepang di Asia Tenggara terbagi menjadi dua gelombang, yaitu pada periode 1975-1985 dan 1985-1990.

Pada tahun 1985 investasi Jepang sebesar 48\% untuk proyek-proyek yang sebagian besar berhubungan dengan sumber daya alam. Investasi Jepang ke negara-negara ASEAN bertambah besar sejak tahun $1986 .{ }^{11}$ Perkembangan ekonomi industri berjalan secara cepat di Vietnam dan Philipina berkat investasi asing dari Taiwan. Hal ini menunjukkan bahwa betapa pentingnya peranan etnis Cina dalam perekonomian di Asia Tenggara. Peranan etnik Cina dalam perekonomian Asia Tenggara tampak pula dengan adanya pasangan bisnis etnik Cina lokal yang meningkat di Asia Tenggara dalam tahun 1980-an. Pepatah yang berbunyi : “bisnis - etnis Cina - keluarga”, kiranya dapat dipahami. Di Thailand, terjadi perkawinan silang baik antara golongan bawah dengan pedagang kecil Cina maupun antara kalangan pengusaha etnis Cina dengan kalangan elite Thailand. Di Jawa dan Sumatra, aliansi di tingkat elite jarang sekali berakhir dengan pernikahan silang. Berkaitan dengan pengalaman komunitas pengusaha Cina di Jawa dan Sumatra tampaknya cukup berharga untuk meneliti dampak ekonomi dari kebiasaan dan peran komunitas pengusaha Cina lain di Asia Tenggara. ${ }^{12}$

Negara-negara di Asia Tenggara di mana terdapat komunitas etnis Cinanya kuat adalah negara-negara yang pertumbuhan ekonominya baik. Sebagaimana telah disebutkan pada bagian terdahulu bahwa jumlah etnis Cina pada tahun 1960 di Singapura mencapai 75\% dari total penduduk, Malaysia : 37\% dan Thailand : 10\%, ketiga negara ini mengalami kemajuan ekonomi yang pesat. Etnis Cina di Indonesia pada tahun 1960 hanya sebesar 2,9\% dan di Philipina lebih kecil lagi, yaitu 0,67\%, suatu kenyataan ekonomi di kedua negara ini berada di belakang ketiga negara tersebut. Lagi pula di Indonesia, etnis Cina dalam masa Orde Baru mendapat tekanan dari pemerintah sehingga

${ }^{11}$ Mari Pangestu (1993). "Perekonomian Asia Timur, Menguatnya Ikatan Regional, Prisma No. 4. hlm.32.

12 Twang Peck Yang. Elite Bisniis Cina di Indonesia dan Masa Transisi Kemerdekaan 1940-1950. Yogyakarta: Niagara, 1998, hlm. 414. 
dinamika etnis Cina terbatas dan peran mereka tidak begitu besar dalam perkembangan ekonomi. Hanya sedikit sekali orang Cina yang berhasil mengembangkan bisnisnya dengan keuntungan yang luar biasa. Menurut J.A.C. Mackie, keuntungan itu diperoleh dari koneksi-koneksi politik dengan pejabat-pejabat pusat ataupun daerah, seperti Liem Sioe Liong. ${ }^{13}$ Sejak tahun 1974 perekonomian nasional Indonesia didominasi oleh etnis Cina, ${ }^{14}$ artinya di berbagai sektor swasta yang berhubungan dengan perputaran rupiah dipegang dan dikendalikan oleh etnis Cina. Mereka bergerak di bank-bank swasta, perusahaan eksport-import, perusahaan-perusahaan manufaktur, dan industri yang lain.

Di beberapa negara, etnis Cina bukan hanya berkecimpung di dalam bidang swasta, tetapi juga memegang jabatan-jabatan penting di pemerintahan, seperti menteri dan perdana menteri. Sehubungan dengan itu maka peranan etnis Cina tidak saja terdapat di bidang ekonomi tetapi juga di bidang politik. Mereka melibatkan keluarga dan kroni-kroninya untuk mengurusi bisnis-bisnis besar di dalam dan di luar negeri. Di Indonesia , etnis Cina mendominasi sektor komersial dan menguasasi lebih dari 163 perusahaan yang terdaftar di Bursa Efek Jakarta. Akibatnya, adalah lahirlah kapitalis-kapitalis besar yang sering disebut "kapitalis kroni” di Indonesia. Selain itu pertokoan-pertokoan di sepanjang jalan besar di Indonesia, khususnya di Jawa dimiliki oleh orangorang dari etnis Cina. Meskipun jumlah pengusaha pribumi sangat besar 30.000 pada tahun 1984, tetapi perusahaan-perusahaannya miskin sumber daya sehingga ketika terjadi penurunan harga minyak tinggal 10.000 yang bisa bertahan hidup. Jumlah pengusaha pribumi itupun masih lebih kecil persentasenya jika dibandingkan dengan pengusaha non pribumi (etnis Cina) dari total penduduk Indonesia. Secara umum pengusaha etnis Cina lebih kuat dibandingkan dengan pengusaha pribumi.

Dengan demikian etnis Cina memiliki peranan penting dalam perekonomian di Asia Tenggara terkait dengan kegiatan-kegiatannya di bidang ekonomi. Mereka bukan hanya melakukan aktivitas dalam produksi barang, distribusi barang dan pemasaran barang yang dibutuhkan manusia, melainkan

${ }^{13}$ J.A.C. Mackie, dalam Richard Tanter \& Kenneth Young. Politik Kelas Menengah Indonesia. Jakarta: LP3ES, 1993, hlm.127.

${ }^{14}$ Thee Kian Wie, July 1994, “Reflections on Indonesia’s Emerging Industrial Nasionalism”, Working Paper No.41, hlm.1. 
juga dalam kegiatan komersial, arus uang dan percepatan perputaran uang yang meningkat sejak tahun 1970. Sebagian penghasilan dari sumber ini mengalir ke etnis Cina daripada ke kaum pribumi, sekaligus ini merupakan sumber penghasilan negara. Penghasilan negara yang lain berasal dari investasi etnis Cina ( dari saham, bunga atau deposito, pinjaman dan yang lain ), meskipun di Indonesia termasuk sangat kecil, tetapi di Singapura, Thailand dan Malaysia lebih besar dibandingkan dengan Indonesia. Sudah tentu beberapa hal itu hanya sekedar contoh kecil, kegiatan komersial masih banyak yang dilakukan oleh etnis Cina yang menjadi sumber pendapatan negara.

\section{E. Kesimpulan}

Dalam perkembangan ekonomi Negara-negara Asia Tenggara, peranan etnis Cina tidak dapat diabaikan begitu saja. Pada tahun 1970-an pertumbuhan ekonomi Asia Tenggara tidak dapat dilepaskan dari politik ekonomi Asia Timur. Jaringan bisnis Cina sudah terwujud dan memiliki peran dominant dalam ekonomi regional Asia Tenggara. Peranan etnik Cina juga nampak dengan adanya pasangan bisnis etnik Cina local di Asia Tenggara tahun 1980an. Negara-negara Asia Tenggara dengan komunitas etnik Cina kuat adalah Negara yang pertumbuhan ekonominya baik. Di beberapa Negara, etnik Cina tidak hanya berkecimpung di dalam bidang swasta, melainkan juga memegang jabatan-jabatan penting dalam pemerintahan. Peranan dalam bidang politik juga diperuntukkan bagi perkembangan bisnis mereka. Mereka melibatkan keluarga dan kroni-kroninya untuk mengurusi bisnis-bisnis besar di dalam maupun di luar negeri.. Etnis Cina tidak hanya melakukan aktivitas dalam produksi barang, distribusi barang dan pemasaran barang yang dibutuhkan manusia, tetapi juga dalam kegiatan komersial, arus uang dan percepatan perputaran uang yang meningkat sejak tahun 1970-an.

\section{Daftar Pustaka}

Abdullah Zakaria Ghazali (ed.al.). (2000). Sejarah Asia Tenggara, Asia Selatan dan Asia Timur 1800-1963. Selangor: Fajar Bhakti.

Jeniffer Cushman dan Wang Gungwu, (1991). Perubahan Identitas Orang

Cina di Asia Tenggara, Jakarta : Pustaka Utama Grafiti.

Jurnal Studi Jepang, (1992). Vol.1 No 2. 
Mackie, J.A.C, (1991). "Peran Ekonomi dan Identitas Etnis Cina Idonesia dan Muangthai” dalam bukunya Jeniffer Cushman dan Wang Gungwu, Perubahan Identitas Orang Cina di Asia Tenggara, Jakarta : Pustaka Utama Grafiti.

Mari Pangestu, (1993). "Perekonomian Asia Timur, Menguatnya Ikatan Regional”, Prisma No. 4.

Tanter, Richard \& Kenneth Young. (1993). Politik Kelas Menengah Indonesia. Jakarta: LP3ES.

Thee Kian Wie, (1994). "Reflections on Indonesian`s Emerging Industrial Nationalism”, Warking Paper No,41 July.

Twang Peck Yang. (1998). Elite Bisniis Cina di Indonesia dan Masa Transisi Kemerdekaan 1940-1950. Yogyakarta: Niagara.

Victor Purcell, (1968). The Chinese in Southeast Asia, London : Oxford University Press.

Wang Gungwu, (1996). "Sojourning: the Chinese Experience in Souteast Asia, in Anthony Reid, ed., Sojourners and Settlers: Histories of Souteast Asia and the Chinese, Australia: Alen and Unwin.

Yoshihara Kunio, (1990). Kapitalisme Semu Asia Tenggara, Jakarta : LP3ES.

Biodata penulis: Danar Widiyanta, Pendidikan S-1 IKIP N Yogyakarta Jurusan Pendidikan Sejarah, Pendidikan S-2 UI Bidang Ilmu Sejarah, mulai 1994 menjadi dosen pada Program Studi Ilmu Sejarah, Jurusan Pendidikan Sejarah, Fakultas Ilmu Sosial dan Ekonomi, Universitas Negeri Yogyakarta. Mengampu mata kuliah Sejarah Asia Tenggara, Historiografi dan Sejarah Pemikian. 